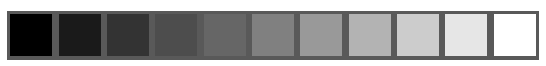

\title{
Inés de Atienza: la hechicera del río Amazonas*
}

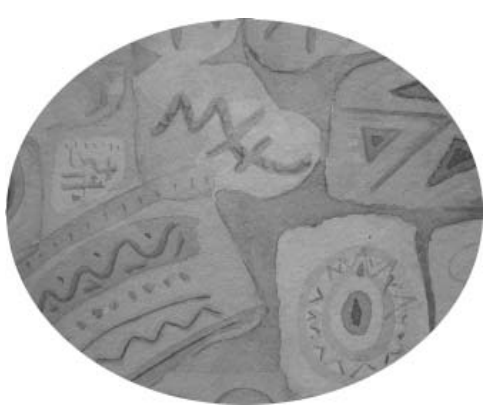

\author{
Elsa Otilia Heufemann-Barria** \\ Natalia Pereira da Costa*** \\ Franciana Ribeiro Sales****
}

\begin{abstract}
Resumo
O imaginário europeu veio junto com os "conquistadores" ibéricos ao Novo Mundo e, com eles, o preconceito e a perseguição às chamadas bruxas ou feiticeiras. $\mathrm{Na}$ expedição que pretendia encontrar e povoar os reinos de Omagua e El Dorado através do rio Amazonas, em 1560, a mestiça Inés de Atienza foi acusada de possuir poderes ocultos, de ter enfeitiçado o capitão Ursúa, de ser a responsável pela morte do capitão e pelo fracasso da expedição. Nessa época, que coincidiu com o período da Inquisição, as feiticeiras eram castigadas com humilhações públicas, multas, açoites e até com a morte.
\end{abstract}

Palavras-chave: Imaginário. Feiticeira. Poder oculto. Mulheres.

\section{Abstract}

The European mindset came along with the Iberian "conquistadores" to the New World. Along with them there came the prejudice and the persecution of the so-called

\footnotetext{
* Este trabalho é resultado de Projeto de Pesquisa do Departamento de Línguas e Literaturas Estrangeiras (DLLE) da Ufam.

** Doutora em Literatura Espanhola e Hispano-Americana pela USP/SP. Professora do DLLE da Ufam.

*** Aluna de graduação do curso de Letras-Língua Espanhola da Ufam.

**** Aluna de graduação do curso de Letras-Língua Espanhola da Ufam.
} 
witches or voodoo priestesses. During the expedition along Amazonas River in 1560, which had the purpose of discovering and inhabiting the kingdoms of Omagua and El Dorado, the mestiza Inés Atienza was accused of possessing occult powers and having charmed Captain Ursúa and having being responsible for his death and for the failure of the expedition. At this time that coincided with the period of the Inquisition, the witches used to be punished with public humiliation, fines, whipping and even with death.

Keywords: Mindset. Witch. Occult powers. Women.

Magia ha existido siempre. Desde tiempos remotos el hombre ha intentado conseguir a través de medios sobrenaturales lo que no podía alcanzar por vías comunes. Para lograr esto se valía de fuerzas ocultas. La creencia en la brujería es común en numerosas culturas, y está o ha estado presente en diferentes periodos en todos los puntos del planeta, y las interpretaciones sobre este fenómeno varían significativamente de una cultura a otra.

La magia formaba parte del imaginario europeo, que durante la Edad Media se nutría de leyendas surgidas de recónditos lugares de África, China y Asia, o de leyendas musulmanas y sobre todo bretonas. La imaginación de los hombres se inflamaba ante los relatos de viajeros que llegaban desde esos lugares, en los siglos XIII y XIV, que describían con precisión su recorrido por las regiones asiáticas. La familia Polo (Nicolo, Maffeo y Marco) y sus relatos llenos de fábulas muchas veces inverosímiles, fueron construyendo entre los habitantes ávidos de novedades, un mundo imaginario entrevado con la realidad. Estos viajantes afirmaron haber oído hablar de monstruos y de tierras fabulosas. En la época, en Europa se sospechaba que existía, en lugares distantes, un mundo nuevo que tenía que ser descubierto, y que se trataba de un universo incomparable por su riqueza y poseedor de escenarios fantásticos, donde todo se tornaba verosímil. Todo esto creó "una intensa curiosidad que despertaba el anhelo de la aventura, y algo de eso se combinaba con la fe para mover al peregrino y al cruzado a abandonar sus lares en busca de tierras lejanas" (ROMERO, 1992, p. 154).

Durante la Edad Media los hombres no percibían los límites entre la realidad y lo imaginario. Se mantenía la tradición milenaria de creer en la existencia de seres sobrenaturales y de tesoros magníficos en aquellos espacios inexplorados o

60 Somanlu, ano 9, n. 1, jan./jun. 2009 
semiexplorados, ubicados en lugares remotos, donde convivían monstruos, hadas, gigantes, ciudades de oro, brujas y hechiceras. El Nuevo Mundo encajaba perfectamente con este espacio, donde los relatos exagerados sobre seres diferentes y monstruosos y de grandes riquezas respaldaron la proliferación de las maravillas en este lugar.

Con la mentalidad medieval llegaron los conquistadores a tierras americanas, guerreando contra los infieles, embreñados en un mundo distante y fabuloso para conquistar tierras remotas, ganar honra y difundir la fe cristiana.

Para entender mejor este imaginario, se buscó como subsidio las categorías de lo sobrenatural que el medievalista Jacques Le Goff (1990, p.22) reconoce que existieron en el Occidente Medieval: lo miraculosus, que corresponde a lo sobrenatural propiamente cristiano, que se refiere a la interferencia de seres milagrosos unidos al cristianismo; lo magicus, que se orienta hacia lo sobrenatural maléfico o satánico, producto de la interferencia del demonio; y, finalmente, mirabilia, que se caracteriza por el predominio de seres mitológicos precristianos y que se considera como tal, a cualquier situación maravillosa que no sea ni cristiana ni demoníaca. De las tres categorías precedentes, nos detendremos en la que se refiere a lo mágico, por la propuesta del presente artículo.

En el Occidente cristiano, la brujería se ha relacionado frecuentemente con la creencia en el Diablo. Llegado el cristianismo, la Iglesia Católica condenó esta práctica y, el 5 de diciembre de 1484, el papa Inocencio VIII da por oficial la existencia de la brujería por medio de la bula Summis desideratis affectibus, impulsando de esta manera la gran caza de brujas. Se produjo entonces una persecución en Europa hacia las brujas, producto de las palabras usadas en la bula, que culpaban a los adoradores del diablo de innumerables males morales:

[...]Y por sus encantos, hechizos, conjuros, sortilegios, crímenes y actos infames, destruyen y matan el fruto en el vientre de las mujeres [...] Destruyen las cosechas [...] Afligen y atormentan con dolores y males atroces $[\ldots]$ e impiden que los hombres puedan engendrar y las mujeres concebir [...] Que los maridos cumplan el deber conyugal con sus mujeres y las mujeres con sus maridos $[\ldots]$ No temen cometer y perpetrar, a instigación del enemigo del género humano, otros muchos excesos y crímenes abominables [...] (ELLIOT, 2005, p. 82). 
Según Julio Caro Baroja (2003, p. 89) se denomina brujas (existe también la forma masculina, brujos, aunque es menos frecuente) a aquellas personas supuestamente dotadas de ciertas habilidades mágicas que emplean con la finalidad de causar daño. Brujería vendría a ser el conjunto de creencias, conocimientos prácticos y actividades de estas personas. Algunos autores, incluso Caro Baroja, han establecido diferencias entre la hechicera y la bruja que las distinguen entre sí. La primera, conocida desde la antigüedad clásica, es una mujer urbana, ancestral y local que trabaja de modo independiente para ganarse la vida (adivinadora, partera, curandera), se sirve de fórmula secretas para conseguir sus propósitos, además de llevar un pacto implícito con el demonio, pero sin renegar de la fe católica. La segunda, por su parte, apareció como una figura degenerada de la hechicería, irreal, anónima, sobrenatural, pervertida por el diablo y de intenciones malvadas y sanguinarias. Es una mujer rural que no se gana la vida a fuerza de sus prácticas, y tiene un pacto explícito con el demonio. Este tipo de mujeres realiza rituales mágicos, llamados aquelarres ${ }^{1}$ para adorar y rendir culto al demonio, a los que se dirigen volando en escoba o en algún animal. Además, por renegar de la fe católica públicamente, fueron perseguidas a lo ancho y largo de la península Ibérica durante el periodo de la Inquisición, en los siglos XVI y XVII, acusadas por causar daño como arruinar cosechas y ganados, secuestrar a niños y beber su sangre y esterilizar tanto a varones quanto a mujeres.

Tanto la bruja rural como la hechicera urbana pertenecían en general a clases sociales marginadas, lo que las hacía más vulnerables a las persecuciones, y se cree que las artes de ambas eran transmitidas oralmente de generación en generación (CARO BAROJA, 2003, p. 90). A pesar de la clara distinción entre brujas y hechiceras registrada precedentemente, en el cotidiano no se les establecía diferencias y, hasta hoy en día, son usadas indistintamente ambas expresiones para referirse a personas que son portadoras de algún poder oculto. Incluso, es posible comprobar esta indistinción en estudios sobre el asunto, que más adelante son citados.

El poder de embrujar o de hechizar es generalmente femenino, porque se consideraba a la mujer más inclinada al pecado, más receptiva a la influencia del demonio, y, por lo tanto, más susceptible de convertirse en bruja o hechicera. En la mayoría de los relatos de brujería se presenta el típico tema de las relaciones entre el hombre y las fuerzas mágicas de la existencia, personificadas generalmente en la mujer como prototipo de la bruja y la hechicera. Según registros, los Tribunales Inquisitoriales españoles ocasionaron menos muertes por la práctica de brujería o hechicería que otros países

62 Somanlu, ano 9, n. 1, jan./jun. 2009 


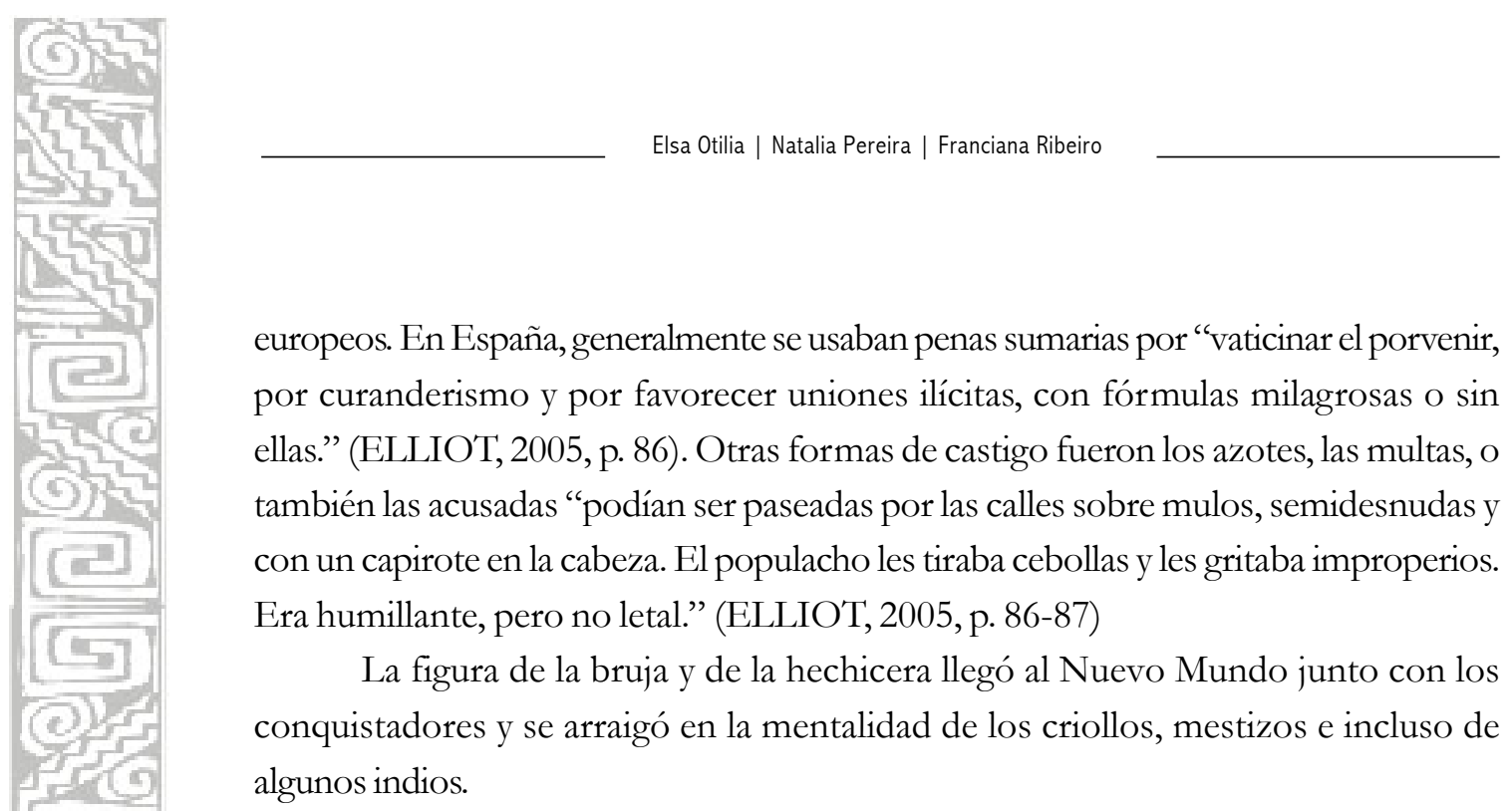

la hechicera de las regiones de América, es heredera en ciertos aspectos de la cultura popular europea, y se vincula, además, a las tradiciones mágicas indígenas, respondiendo a importantes requerimientos que la sociedad colonial tenía sobre todo con las mujeres de los sectores más pobres. Podría sostenerse que la hechicera americana fue una mujer que solucionaba, o por lo menos consolaba, en las situaciones difíciles de las relaciones humanas, las cuales ni las instituciones ni medios tradicionales podían resolver (ARRE MARFULL, 2006).

La misma autora sostiene que el hecho que se recurra a la hechicería por cuestiones sentimentales es una peculiaridad más frecuente en América, y menos recurrente en Europa, y que la fuerza excepcional de la hechicería amorosa estaría vinculada al clima moral excepcionalmente permisivo que se daría en esta parte de América, como era el Virreinato peruano. Se decía que el concubinato practicado en todos los estratos sociales sería la forma más aceptada de relación entre parejas, sin que fuera considerada inmoral. Lima era presentada por algunos eclesiásticos como un abismo de corrupción encendido por el demonio de la carne.

Estas mujeres utilizaban la magia con frecuencia para abordar problemas amorosos y para resolver conflictos personales y sociales, muchos de los cuales giraban alrededor de relaciones ilícitas, adulterios y violencia conyugal. Generalmente las hechiceras eran indias o mestizas, predominando las solteras y viudas por sobre las casadas, y mayormente de edad madura. 
'brujas', eran mujeres que a través del conocimiento de rituales y de las propiedades de ciertas hierbas lograron tener ascendiente como curanderas y hechiceras. Y además ellas constituyeron, en realidad, las primeras contestatarias del sistema colonial en el que era imposible abrirse un espacio racional ni siquiera en la práctica de una religión que proclamaba la igualdad de los seres humanos. Estas personas habitualmente formaban parte del mundo doméstico de sus amos, se las acusaba, entre otras cosas, por su liviandad sexual y por ladronas y envidiosas, ellas podían perturbar la armonía de la sociedad. Las víctimas de las hechiceras tenían, por lo tanto algún grado de cercanía con ellas. De hecho había un 'carácter doméstico' en el pleito, en donde lo público y lo privado habitualmente se confundía. Los vecinos y los parientes de las hechiceras podían también ser perjudicados por el efecto de su 'arte', por lo que estas personas tendían a ser temidas y a la vez respetadas (GUARDIA, s/f).

El Tribunal del Santo Oficio (1570-1820) tuvo una decidida presencia en el Peru durante 250 años, en los cuales persiguió y condenó a mujeres acusadas de prácticas de hechicería. Esta persecución y prejuicio se hacía sentir en cualquier mujer que era sospechosa de poseer algún poder oculto, peligroso e inexplicable. Tal fue el caso de doña Inés de Atienza, una bella y joven mestiza, hija de Blas de Atienza, uno de los primeros conquistadores que se aventuraron por el Nuevo Mundo. Inés fue casada con el español Pedro de Arcos y tuvo amores con Francisco de Mendoza, pariente del virrey Cañete. Su marido murió en un duelo por honor enfrentando a Mendoza. Posteriormente la viuda conoce al capitán Pedro de Ursúa, quien decide llevarla en la expedición que estaba bajo su comando, haciendo oídos sordos de los comentarios y de las presiones, incluso de las autoridades, para que no lo hiciera. El objetivo de la jornada era encontrar las tierras de El Dorado, aquella fantástica ciudad imaginada por los conquistadores, cuyas calles estaban asfaltadas en oro. Con fecha 26 de septiembre de 1560 parte del embarcadero de Topesana (Perú) la mal organizada expedición, con aproximadamente mil componentes, entre españoles, indios, negros y algunas mujeres. Poco tiempo después de zarpar comenzaron los problemas con las embarcaciones mal construidas, después surgieron dificultades por la falta de comida, por la falta de comando del capitán y por las amenazas de motines, todo lo cual era

64 Somanlu, ano 9, n. 1, jan./jun. 2009 


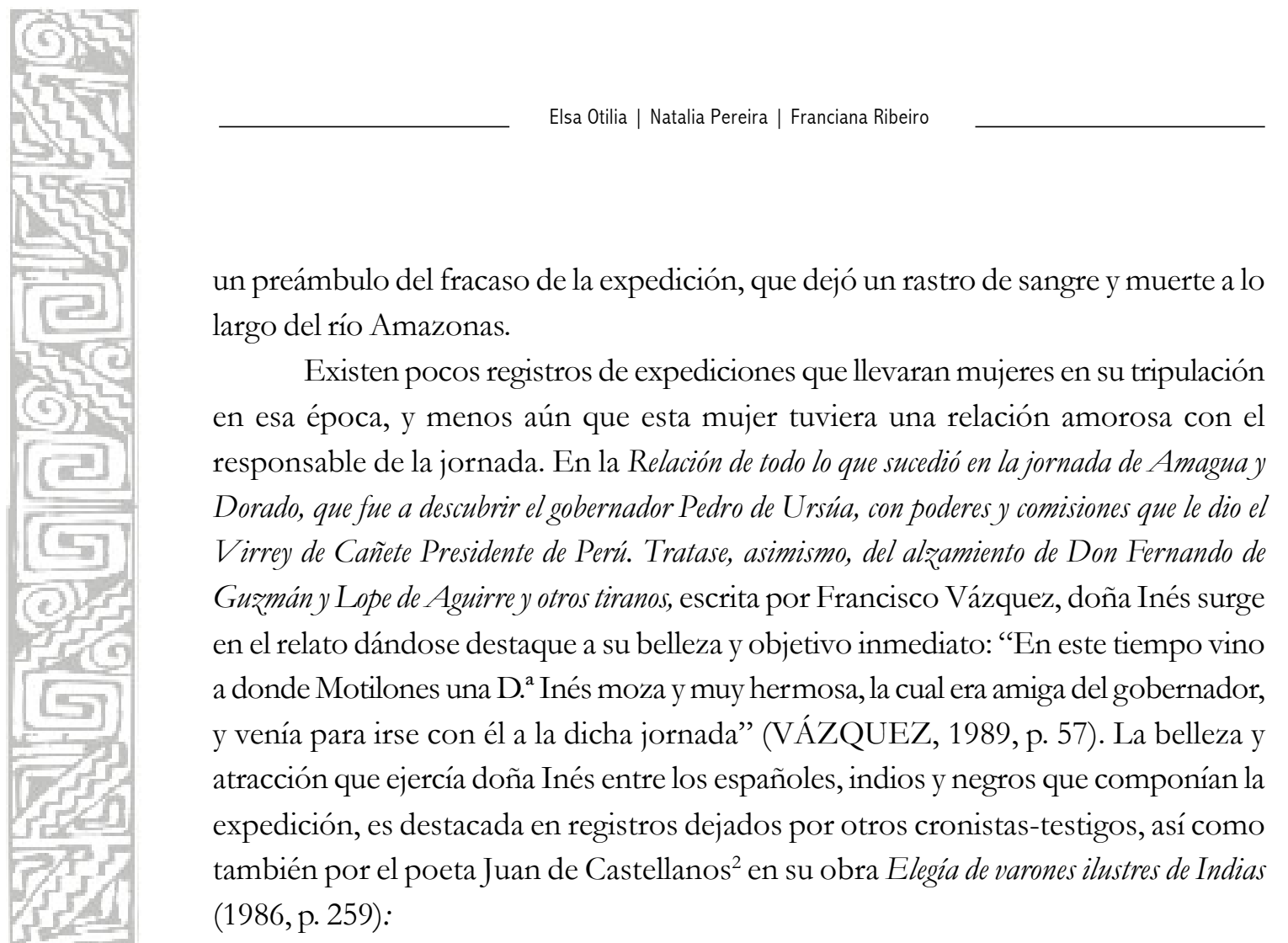

La bella doña Inés era la dama

Que tuvo con razón nombre de bella,

Si fuera con reguardo de fama

Que debe reguardar cualquier doncella;

A quien el buen Ursúa mucho ama,

Siendo no menos él amado della;

$\mathrm{Y}$ como bien querer importunase

Acabose con él que la llevase.

(Elegía XIV - Canto III)

La belleza de una mujer en esas circunstancias era un elemento negativo y, en el caso de Inés, ella enceguecía, incomodaba e irritaba a los expedicionarios que querían poseerla y dominarla, provocándoles un sentimiento de impotencia y rabia hacia ella y de envidia hacia Pedro de Ursúa, porque "junto a su alojamiento la dicha doña Inés, sólo a fin (según parecía) de que nadie le estorbase sus amores[...]" (VÁZQUEZ, 1989, p. 72). Al parecer la perturbadora belleza de la mestiza llevó al delirio a muchos de estos hombres. 
Aparentemente durante la bajada por el río Amazonas el capitán Ursúa se enferma, puesto que cambia de actitud en el comando y se aísla. "y echaron sobre ello algunos juicios y concluyeron que el gobernador estaba en aquella sazón malo, y que podría morir de aquella enfermedad [...]" (VÁZQUEZ, 1989, p. 77). Sin embargo, como ya existían focos de rebelión y el descontento entre los expedicionarios iba en aumento, Lope de Aguirre, que tenía objetivos políticos diferentes de los del gobernador, aprovechó estas circunstancias para liderar un motín que llevó al asesinato de Ursúa. Posteriormente las muertes violentas y las traiciones se suceden, hasta terminar la jornada con la detención y muerte del caudillo Aguirre, acabando con las esperanzas de encontrar el tan codiciado reino de El Dorado.

La mayoría de los cronistas que dejaron relatos escritos sobre los sucesos de esta expedición, que fueron más de diez, afirmaron que doña Inés habría sido la responsable por la muerte del capitán Ursúa y por el fracaso de la expedición. Francisco Vázquez recuerda:

bien contra la opinión de los amigos del gobernador que se lo estorbaban, y él lo hizo contra la voluntad de todos, de lo cual pesó a la mayor parte del campo, lo uno por el mal ejemplo y lo otro porque se decía que la dicha $\mathrm{D}^{\mathrm{a}}$ Inés tenía mala fama y peores hechos y mañas, la cual fue la causa principal de la muerte del gobernador y de nuestra total destrucción (1989, p. 57).

Ursúa le destina a Inés la mejor embarcación y le dedica practicamente todo su tiempo, descuidando el gobierno de sus hombres y olvidándose cuál es su rol, "habíase hecho remiso y descuidado en la buena gobernación y disciplina de su campo y armada, y mal acondicionado y desabrido, que los que primero le conocíamos, unos con otros decíamos que no era posible que fuera Pedro de Ursúa, o que no debía estar en su propio juicio" (VÁZQUEZ, 1989, p. 80). Además se muestra inhábil y débil en la resolución de los problemas. Sus hombres se ven abandonados y Vázquez se refiere al asunto de la siguiente manera:

[...] y a esta razón el gobernador iba mal quisto con la mayor parte del campo, que eran ruínes y mal intencionados porque no les dejaba robar y atar indios, ranchearles y matarlos a diestro y siniestro, y decían que desde entonces tenía la

66 Somanlu, ano 9, n. 1, jan./jun. 2009 


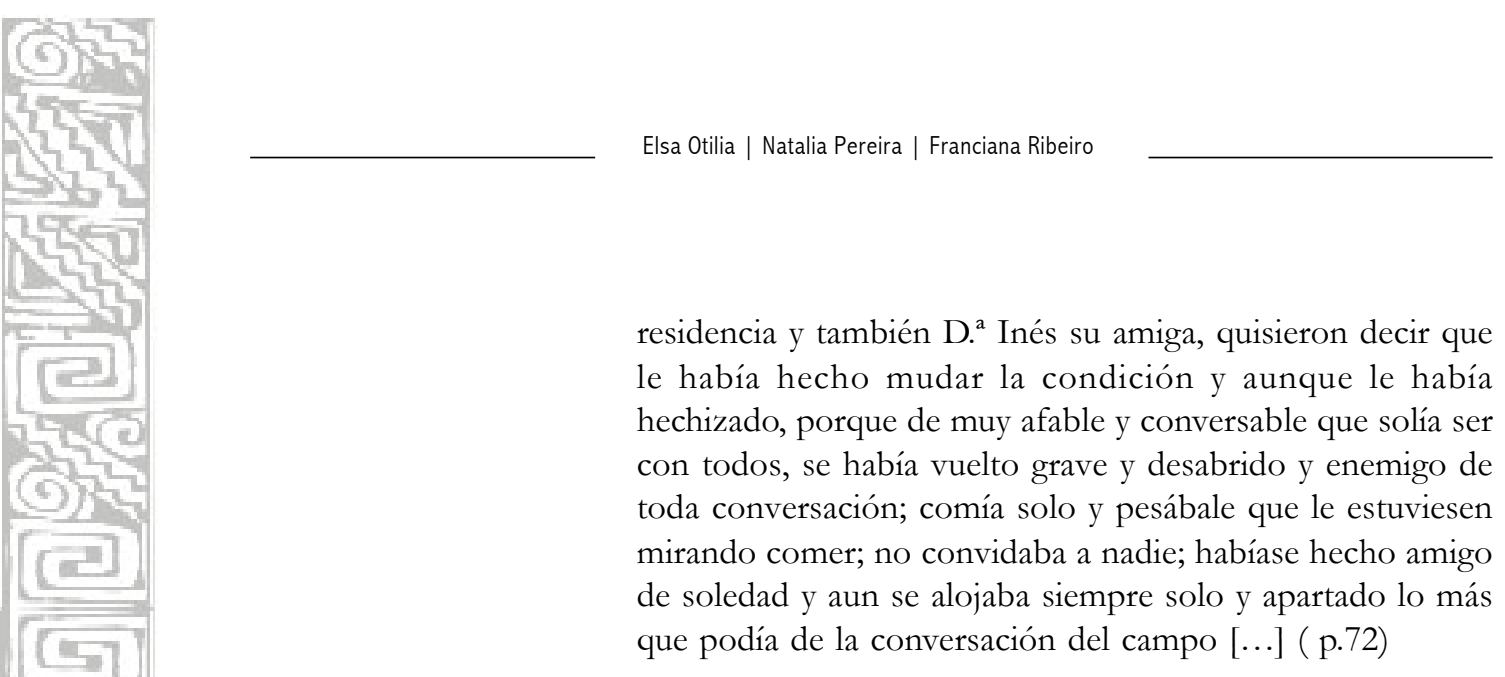

En este momento doña Inés es acusada de hechicería por haber provocado el cambio en el comportamiento de Ursúa. Esta acusación no era incomún en la época, por diferentes motivos que ya fueron citados precedentemente. Entre las características que poseía doña Inés, que coincidían con aquellas de quien ejercía la brujería y/o la hechicería, es posible citar la atracción sexual y el enamoramiento, que eran vistos por los hombres como prácticas negativas, por lo general atribuidas al empleo de magia por parte de las mujeres. Según la historiadora Michelle Perrot, en nombre de la ciencia y de la racionalidad occidental a las brujas se les reprochaba que manifestaban "una sexualidad desembozada: tienen la vagina insaciable y practican una sexualidad subversiva" (2008, p. 114). Sumado a la atracción física que provocaba doña Inés, existía el mestizaje de su origen, que según se entendía en la época, la hacía portadora de poderes ocultos, peligrosos y de la utilización de medios diabólicos para dominar a las personas, por lo cual la colocaban en una posición antagónica al bien. Debido a la atracción que doña Inés ejercía entre los expedicionarios, estos temieron que ella fuera depositaria de poderes ocultos y todos sucumbieran a sus hechizos, como ocurrió con Juan Alonso de la Bandera y Lorenzo de Salduendo, teniente general y Maestre de Campo, respectivamente, de Lope de Aguirre, quienes se disputaban el amor de doña Inés después del asesinato de Ursúa, motivo por el cual ambos acabaron muertos (ALMESTO, 1986, p. 136). Doña Inés de Atienza era viuda y habitaba en la ciudad, lo que también favorecería su condición de hechicera en Perú. De acuerdo a estudios realizados por Alejandra Osorio las curanderas y hechiceras de Lima fueron mujeres de los estratos populares y muchas de ellas fueron mujeres solteras o viudas, frecuentemente migrantes de otros lugares del virreinato y no fue patrimonio exclusivo de un grupo étnico o $\operatorname{social}(1999$, p. 62).

Ursúa demuestra indiferencia ante los consejos y propuesta de algunas personas para que desistiera de llevar a doña Inés. Tal fue el caso narrado por Vázquez, que se 
declara testigo de la preocupación de don Pedro de Añasco, un "caballero muy principal del Peru” (1989, p. 77) y amigo de Pedro de Ursúa, quien le envía una carta al capitán diciéndole que

la ida de doña Inés era escandalosa, y de que pesaba a todos sus amigos, le diese convencimiento a que él hiciese quedar a la dicha doña Inés que aún no estaba dentro de Motilones, y que para esto él se daría buena maña, que ella ni nadie entendiesen que el gobernador había sido causa de la quedada [...] (VÁZQUEZ, 1989, p. 78)

En la Relación consta que en los momentos importantes que los subalternos querían o necesitaban la presencia o la atención de Ursúa, este se encontraba con Inés. Tal es el caso del negro Juan Primero que, sabiendo que estaban tramando la muerte de su capitán, fue a alertarlo aquella noche "tres o cuatro veces", pero el gobernador estaba encerrado con doña Inés y no pudo darle el aviso. Finalmente, en la Relación de Vázquez se explicita de qué manera el hechizo de doña Inés había surtido efecto en el gobernador:

[...] dígole porque después que se juntó con la D. ${ }^{a}$ Inés mudó costumbres y condición, porque tuvo algunos vicios y resabios, y esto se le había pegado, según se entendió, de la dicha $\mathrm{D}^{\mathrm{a}}{ }^{\mathrm{a}}$ Inés, porque era público le tenía hechizado, lo cual ella sabía muy bien, y así se había trocado muy mucho en condición, porque de muy franco que era se había hecho codicioso [...] habíase hecho remiso y descuidado en la buena gobernación y disciplina de su campo y armada, y mal acondicionado y desabrido, que los que primero le conocíamos, unos con otros decíamos que no era posible que fuera Pedro de Ursúa, o que no debía estar en su propio juicio. (1989, p. 80)

Como corolario a esta serie de conjeturas y acusaciones, la muerte de doña Inés es esperada. Lope de Aguirre mandó a los expedicionarios LLamoso y Carrión para que matasen a la mestiza y "el uno le dio de agujazos y el otro la tomó por lo cabellos y le dio sobre veinte puñaladas y así acabó la pobre señora que era la mayor lástima del mundo. Esta era la más linda dama que en el Perú quedaba [...]" (HERNANDEZ, 1927, p. 287). El poeta español Juan de Castellanos describe hor-

68 Somanlu, ano 9, n. 1, jan./jun. 2009 


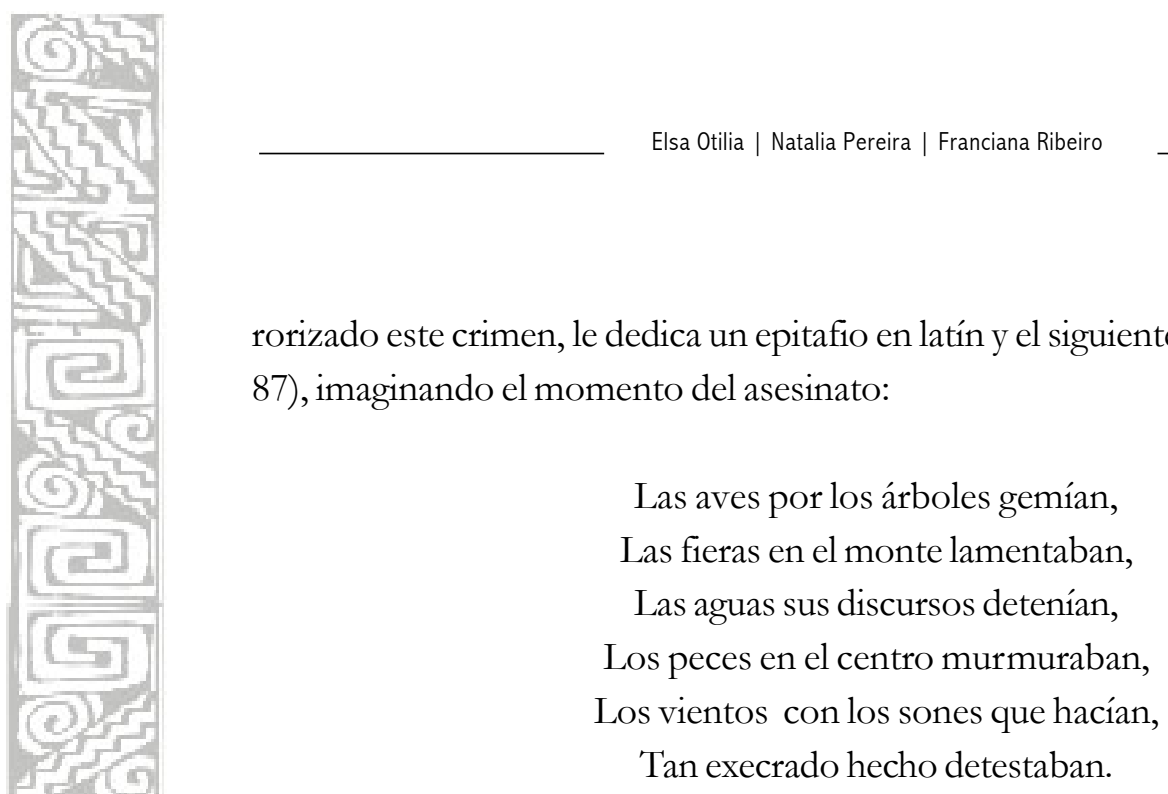

Se puede inferir, por la lectura realizada de la Relación y por el análisis precedente, que las acusaciones hechas a doña Inés probablemente fueron para evitar, por un lado, que los restantes de los expedicionarios fueran acusados del crimen de traición, por participar del motín y especialmente por la muerte de Ursúa; y, por otro, que la fama y la imagen del capitán Pedro de Ursúa no sean denegridas, puesto que era conocido como un hombre muy respetado en el Virreinato, dueño de un pasado heroico en tierras americanas, lo que le predecía un futuro brillante. En ningún trecho de sus relatos, los cronistas consultados, Vázquez, Almesto y Hernández, relatan hechos concretos atestiguados sobre la práctica de hechicería por parte de Inés, solamente la acusan de ello por la aproximación y cierta dependencia que veían por parte del capitán hacia ella. Dentro de la mentalidad colonialista de la época, siglo XVI, y del universo de expedicionarios donde estaba inserta, doña Inés era el lado más débil y vulnerable por ser mujer, joven, hermosa, viuda y mestiza. Si a esto se le agrega el hecho de ser amante del capitán de la expedición, de su pasado de relaciones amorosos y de su fuerte atractivo físico, para los conquistadores y motivados por la coyuntura por la que atravesaban, la mejor salida fue la de acusarla de ser portadora de poderes ocultos para apoderarse de la voluntad del capitán, a tal punto de hacerlo perder el poder de comando y de llevar al fracaso la expedición.

Visto desde otro ángulo, y si nos situamos en la época y en la expedición del siglo XVI, podríamos inferir que las aguas del río Amazonas fueron testigo del inmenso e inexplicable poder oculto de una bellísima hechicera, que nunca nadie la vio preparar pócimas o brebajes enloquecedores, ni volar en una escoba en noches de luna llena, pero que fue capaz de "echar por agua abajo" una de las expediciones 
españolas más importantes de ese siglo. Finalizamos con el soneto "La Hechicera" del escritor mexicano Luis Gonzaga Urbina (1864-1926), que destaca ese poder inexplicable de estas mujeres y que perfectamente podría estar dedicado a doña Inés de Atienza:

\footnotetext{
No sentí cuando entraste; estaba oscuro en la penumbra de un ocaso lento, el parque antiguo de mi pensamiento que ciñe la tristeza, cual un muro.

Te vi llegar a mí como un conjuro, como el prodigio de un encantamiento, como la dulce aparición de un cuento: blanca de nieve y blonda de oro puro.

Un hálito de abril sopló en mi otoño; en cada fronda reventó un retoño; en cada viejo nido, hubo canciones;

y, entre las sombras del jardín -errantes luciérnagas- brillaron, como antes de mi postrer dolor, las ilusiones.
}

\section{Notas}

1 Aquelarre: de akelarre, prado del macho cabrío en euskera. Reunión sabática y nocturna en que brujos y brujas renegaban colectivamente de Dios y prometían fidelidad al demonio. Tras una ceremonia iniciática, viajaban por los aires hasta el lugar del encuentro. Allí se bailaba alrededor del diablo, representado en un trono como un macho cabrío o un hombre negro con cuernos luminosos. Los adeptos abjuraban de Cristo y reconocían a Satanás en calidad de dios y señor. Después se sellaba el pacto. Mediante el pacto, la bruja se comprometía a rendir culto al Diablo a cambio de la adquisición de algunos poderes sobrenaturales (ELLIOT, p. 83).

70 Somanlu, ano 9, n. 1, jan./jun. 2009 


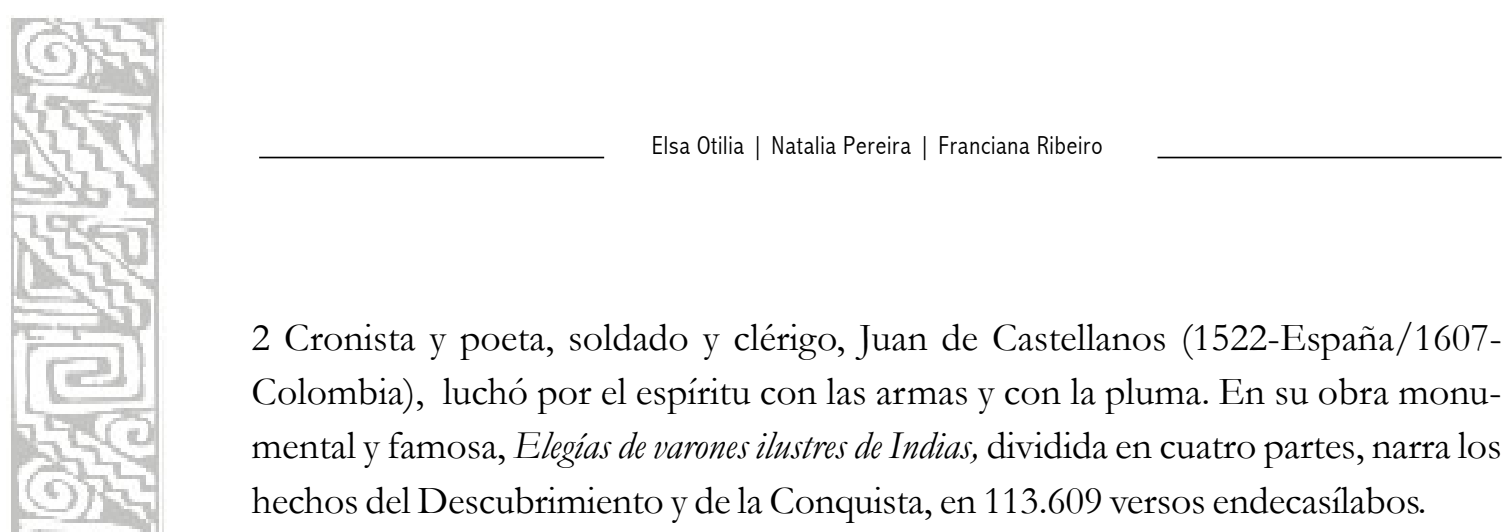

\section{Referências}

ALMESTO, Pedrarias de. Jornada de Omagua y Dorado. In: La aventura del Amazonas. Introducción y notas de Rafael Díaz Maderuelo. Madrid: Historia 16, 1986. n. 19.

ARRE M., Montserrat. Brujería y Hechicería. 2006. Disponible en: <www.futurooculto.com/hechiceria-y-brujeria/pagina_2/> Acceso en: 20 nov.2008

CARO BAROJA, Julio. El Señor Inquisidory otras vidas por oficio. Madrid: Alianza, 1997. . Las brujasy su mundo. Madrid: Alianza, 2003.

CASTELLANOS, Juan de. Elegía de varones ilustres de Indias. Época virreinal, Madrid: Alhambra, 1986.

ELLIOT, Julián. Revista Historia y Vida, n. 450, Madrid, 2005

LE GOFF, Jacques. O Maravilhoso e o quotidiano no ocidente Medieval. Lisboa: Edições 70, 1990.

GUARDIA, Sara Beatriz. Las mijeresy la recuperación de la historia. Disponible en: < http:/ /webserver.rcp.net.pe/cemhal/capitulo1.html>. Acceso en: 15 mayo 2009

HERNANDEZ, Custodio. Relaçión muy berdadera que trata de todo lo que acaeçió en la entrada de Pedro de Ursúa... In: JOS, Emiliano. La expedición de Ursúa al Dorado y la rebelión de Lope de Aguirre. Huesca (España): Ed.V. Campos, 1927.

JOS, Emiliano. La expedición de Ursúa al Dorado y la rebelión de Lope de Aguirre. Huesca (España): Ed.V. Campos, 1927.

OSORIO, Alejandra. Hechicerías y curanderías en la Lima del siglo XVII. Formas femeninas de control y acción social. In: ZEGARRA, Margarita (org.). Mujeres y género en la bistoria del Perú. Lima: Cendoc Mujer, 1999. p. 59-75.

OVIEDO, José Miguel. Historia de la Literatura Hispanoamericana. De los orígenes a la emancipación. Madrid: Alianza, 2004.

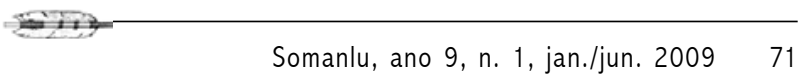


PERROT, Michelle. Mi historia de las mujeres. 1. ${ }^{a}$ Edición en español. Buenos Aires: Fondo de Cultura Económica, 2008.

ROMERO, José Luis. La Edad Media. México: Fondo de Cultura Económica, 1992.

URBINA, Luis. La hechicera. Disponible en: < www.poesiaspoemas.com/luis-g.urbina/hechicera >. Acceso el: 25 de mayo de 2009.

VÁZQUEZ, Francisco. "Relación de todo lo que sucedió en la jornada de Amagua y Dorado, que fue a descubrir el gobernador Pedro de Ursua, con poderes y comisiones que le dio el Virrey de Cañete Presidente de Perú. Tratase, asimismo, del alzamiento de Don Fernando de Guzmán y Lope de Aguirre y otros tiranos”. In: ElDorado:Crónica de la expedición de Pedro de Ursúa y Lope de Aguirre. Introducción y notas de Javier Ortiz de la Tabla. Madrid: Alianza, 1989.

72 Somanlu, ano 9, n. 1, jan./jun. 2009 